\title{
Synthesis and Characterization of New heterocyclic Polyacrylamides from Derivatives 2-Aminobenzothiazole
}

\author{
Entesar O. Al-Temimi* Mahmoud A.AL-Issa ** \\ Sameaa J. Al-Bayati**
}

Received 20, December, 2012

Accepted 5, February, 2014

\begin{abstract}
:
The present work involved preparation of new hetro cyclic polyacrylamides (1-9) using reaction of polyacryloyl chloride with 2 -aminobenzothiazole which prepeard by thiocyanogen method in the presence of a suitable solvent and amount tri ethyl amine $\left(\mathrm{Et}_{3} \mathrm{~N}\right)$ with heating. The structure confirmation of polymers were proved using FTIR, ${ }^{1} \mathrm{H}-\mathrm{NMR}, \mathrm{C}^{13} \mathrm{NMR}$ and UV spectroscopy.Other physical properties including softening and melting points, and solubility of the polymers were also measured.
\end{abstract}

Key words: polyacrylamides, poly acryloyl chloride, 2-Aminobenzothiazole

\section{Introduction:}

Polyacrylamide is apolymer $\left(-\mathrm{CH}_{2} \mathrm{CHCONH}_{2-}\right)$ formed from acrylamide subunits. It can be synthesid as asimple linear -chain structure or cross-linked, typically using N,N'-methyllenebisacrylamide. Polyacrylamide is not toxic .however, unpolymerized acrylamide, which is aneurotoxin, can be present in very small amounts in the polymerized acrylamide, ${ }^{[1-2]}$ therefore it is recommended to handle it with caution. In the cross-linked form, the possibility of the monomer being present is reduced even further. It is highly water- absorbent, forming asoft gel when hydrated, used in such applications as poly acrylamide gel electrophoresis and in manufacturing soft contact lenses. In the straightchain form, it is also used as athickener and suspending agent one of the largest uses for polyacrylamide is to flocculate solids in aliquid.this process applies to water treatment, and processes like paper making. Polyacrylamide can be supplied in apowder or liquid form, with the liquid form being subcate gorized as solution and emulsion

*Dep. Of Chemistry College of Science University of Baghdad Iraq

**Dep. of Chemistry College of Science for women, University of Baghdad Iraq

polymer. Another common use of poly acrylamide and it's derivatives are in subsurface applications such as enhanced oil recovery. ${ }^{[3-4]}$ The polymer is also used to make Gro-Beasttoys, which expand when placed in water, such as the Test Tube Aliens. Similariy, the absorbent properties of one of it's copolymers can be utilized as an additive in body- powder. ${ }^{[5-7]}$ Polymacrylamide is often used in molecular biology application as amedium for electrophoresis of proteins and nucleic acids in atechnique known as PAGE .In this paper prepared polyacrylamide by Condensation poly acryloylechloride (PAC)with 2-amino benzothiazole derivatives.2-Aminobenzothiazole compounds are considered one of an important type of fused thiazoles anumber of 2-aminobenzothiazoles and derivatives were prepared by two methods. The first is Hugersch's method which concerns the reaction of thiourea derivatives with bromine in acetic acid. The second, thiocyanogen method which concerns the direct reaction of amine derivatives with 
potassium thiocyanate and bromine in glacial acetic acid, They have been studied extensively and found to have diverse chemical reactivity and broad spectrum of biological activity such as antitumor agents, antimicrobial,analgesics,anti-inflammatory. ${ }^{[8-11]}$

\section{Material and methods: \\ General}

Chemicals employed were of analytical grade and used without further purification, melting points were determined in Gallen kamp melting point apparatus and were uncorrected.UV-Visible spectra were recorded on ShimadzuT60u spectrophotometer using ethanol as a solvent, FT-IR spectra were recorded on Shimadzu FT-IR-8400 Fourier Transform infrared spectrophotometer as $\mathrm{KBr}$ disc. ${ }^{1} \mathrm{H}$-NMR and ${ }^{13} \mathrm{C}$-NMR spectra were recorded on Bruker specrospin Ultra shield magnets 300 MHz using tetramethyl silane (TMS)as an internal standared and DMSO.d $\mathrm{d}_{6}$ as asolvent in Al-Albate University in Jordan.

\section{Preparation of 2-aminobenzothiazole Derivatives $^{[12-13]}$}

In a $250 \mathrm{ml}$ round bottomed flask equipped with a magnetic bar stirrer and dropping funnel, a solution of bromine $(1.2 \mathrm{ml})$ in glacial acetic acid $(75 \mathrm{ml})$ was allowed to run through the dropping funnel dropwise during $30 \mathrm{~min}$. to a mixture of para substituted aromatic amine ( 0.03 mole) and ammonium thiocyanate $(0.1$ mole $)$ in $150 \mathrm{ml}$ glacial acetic acid with stirring. The mixture was stirred for 1 hr., then diluted with water and neutralized with solid sodium hydroxide. The precipitated substance was collected, triturated and recrystallized from a suitable solvent.

General Procedure for Preparation of Poly Heterocyclic acrylamides

In around bottom flask equipped with a magnetic bar stirrer was placed a mixture of poly acryloyl chloride (0.06 mole) and (0.06 mole) of 2-aminobenzothiazole derivatives with $(2 \mathrm{ml})$ of $\mathrm{Et}_{3} \mathrm{~N}$ (triethylamine) in $(25 \mathrm{ml})$ of suitable solvent (THF, DMF) and refluxed for (7-10) hrs. After cooling, the excess of solvent was removed under vacum and the solid separated was filtered and purified by dissolving in DMF or DMSO and reprecipitating from water or acetone or ethanol. This procedure was applied on preparation compounds [1-9] as is shown in Table (1).All physical properties are listed in Table (3). 
Table (1): Starting material and conditions of prepared poly heterocyclic acrylamides [1-9]<smiles></smiles>

\begin{tabular}{|c|c|c|c|c|}
\hline $\begin{array}{c}\text { Structure one of starting } \\
\text { material }\end{array}$ & $\begin{array}{l}\text { Weight } \\
\text { (gm) }\end{array}$ & $\begin{array}{c}\text { Time } \\
\text { reaction } \\
\text { hr. }\end{array}$ & Structure of polymer & $\begin{array}{l}\text { No. of } \\
\text { product }\end{array}$ \\
\hline & 2.29 & 7 & & 1 \\
\hline & 2.29 & 8 & & 2 \\
\hline & 1.85 & 7 & & 3 \\
\hline & 2.19 & 9 & & 4 \\
\hline & 1.64 & 7 & & 5 \\
\hline & 1.78 & 7 & & 6 \\
\hline & 1.80 & 10 & & 7 \\
\hline & 1.95 & 8 & & 8 \\
\hline & 2.40 & 9 & & 9 \\
\hline
\end{tabular}

\section{Results and Discussion:}

preparation of $[2$-(N-acryl)amido substituted benzothiazole] [1-9]. New compounds [1-9] were prepared by the reaction of derivatives 2aminobenzothiazole with poly (acryloyl chloride) in the presence of triethylamine $\left(\mathrm{Et}_{3} \mathrm{~N}\right)$. As shown below:<smiles>CC(C)(C)CCC(Nc1nc2cc(P)ccc2s1)C(=O)Nc1nc2cc(Br)ccc2s1</smiles>

$\mathrm{R}=\mathrm{Cl}, \mathrm{NO}_{2}, \mathrm{CH}_{3}, \mathrm{OCH}_{3}$

mechanism of the reaction involves a nucleophilic attack on the carbonyl as is shown below ${ }^{(11)}$ :- 


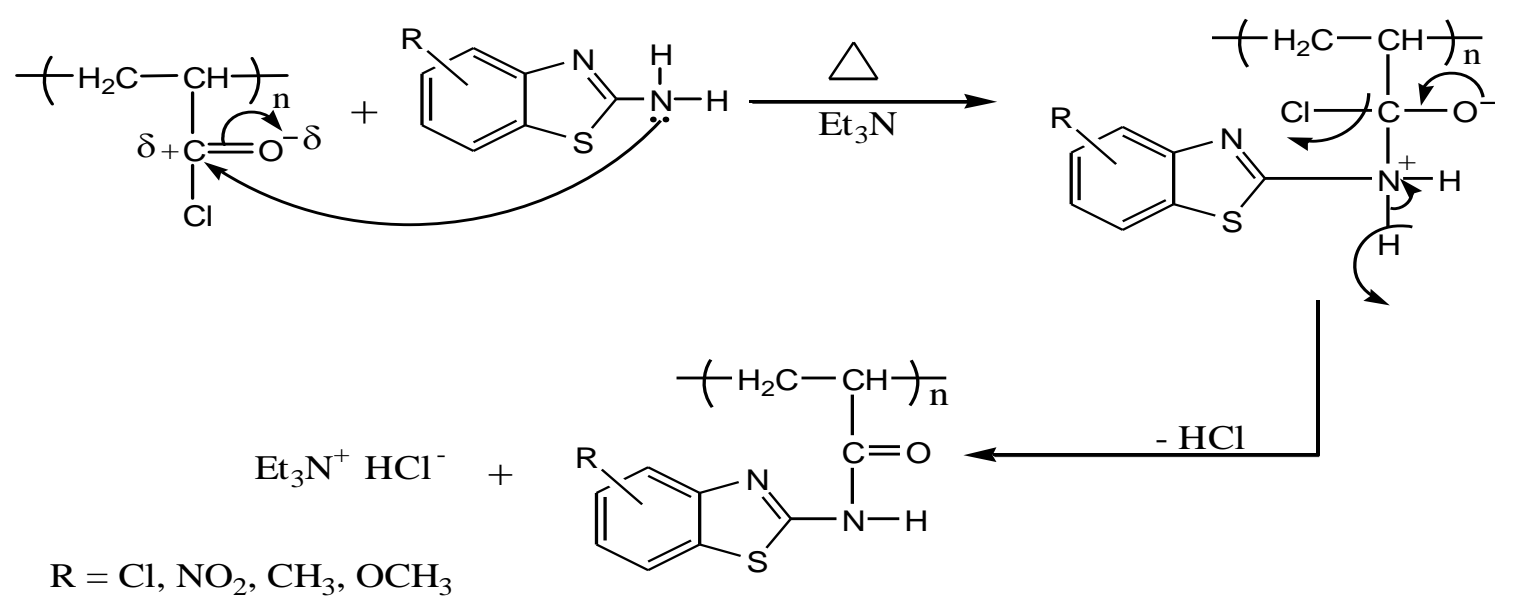

Scheme (1): Mechanism of preparation of poly [2-(N-acryl)amido

\section{substituted benzothiazole]}

Structures confirmation of all prepared polymers were proved using FT-IR, UV, ${ }^{1} \mathrm{H}-\mathrm{NMR}$ and ${ }^{13} \mathrm{C}-\mathrm{NMR}$ spectroscopy. Physical properties including melting point, softening point, solubility and percent conversion of the polymers were also measured. These and other physical properties are summarized in Table (2) and(3).

Poly [2-(N-acryl)amido-4-nitro-6chlorobenzothiazole] [1] was prepared by refluxing poly acryloyl chloride with 4-nitro-6-chloro-2-amino benzothiazole in the presence of triethyl amine $\left(\mathrm{Et}_{3} \mathrm{~N}\right)$ in DMF for $7 \mathrm{hrs}$. Polymer [1] in, was a yellowish brown solid with softening point range of $(185-215)^{\circ} \mathrm{C}$, and its percent conversion was $(76 \%)$. Compounds (29) were synthesized by the same way and purified by dissolving in a suitable solvent such as (THF, DMF, DMSO) with gentle heating and then filtered. The clear filtrate was added to suitable solvents such as (water, acetone, ethanol) and the precipitate was filtered and dried.

FT-IR spectrum of compound [1], in $\mathrm{KBr}$ disk showed characteristic absorption bands at $1620 \mathrm{~cm}^{-1}, 3260$ $\mathrm{cm}^{-1}, 1350 \mathrm{~cm}^{-1}$ and $1140 \mathrm{~cm}^{-1}$ due to
$v(\mathrm{C}=\mathrm{C})$ aromatic, $v(\mathrm{C}-\mathrm{H})$ aromatic, $v\left(\mathrm{C}-\mathrm{NO}_{2}\right)$ and $v(\mathrm{C}-\mathrm{Cl})$ respectively.

Absorption bands due to $v(\mathrm{C}=\mathrm{N})$ and $v(\mathrm{C}-\mathrm{S})$ for thiazole ring appeared at $1512 \mathrm{~cm}^{-1}$ and $635 \mathrm{~cm}^{-1}$ respectively as shown in the Table(4) Fig.(1).

UV spectrum showed an absorption $\lambda_{\max }$ at $274 \mathrm{~nm}$ and $421 \mathrm{~nm}$ which was attributed to $\left(\mathrm{n} \rightarrow \pi^{*}\right)$ and $\left(\pi \rightarrow \pi^{*}\right)$.as shown in Fig.(5).

FT -IR spectrum of compound [2] showed the same bands in compound [1] as shown in Table (4).

UV spectrum showed an absorption $\lambda_{\max }$ at $279 \mathrm{~nm}$ and $344 \mathrm{~nm}$ which was attributed to $\left(n \rightarrow \pi^{*}\right)$ and $\left(\pi \rightarrow \pi^{*}\right)$.

In the ${ }^{1} \mathrm{H}-\mathrm{NMR}$ spectrum of polymer [2] showed a signal at $\delta 8.102 \mathrm{ppm}$ $(1 \mathrm{H}$, singlet) was attributed to $(-\mathrm{NH})$ proton, and the signal at $\delta 2.892 \mathrm{ppm}$ was attributed to $(-\mathrm{CH})$ for polymer group, whil the signal at $\delta 1.125 \mathrm{ppm}$ $(2 \mathrm{H})$ was attributed to the $\left(\mathrm{H}_{2} \mathrm{C}-\right)$ protons, and the signal between $\delta(6.827-6.918) \mathrm{ppm}$ for two aromatic protons $\left(1 \mathrm{H}^{4}, 1 \mathrm{H}^{5}\right)$ as shown in Fig.(8) The ${ }^{13} \mathrm{C}$-NMR spectrum of [2] showed a signal at $162.77 \mathrm{ppm}$ for carbonyl group $(\mathrm{C}=\mathrm{O})$, a signals at 114.02$126.13 \mathrm{ppm}$ due to aromatic carbons, signals at 151.84 ppm belong to carbon 
atom in thiazole ring, showed signals at 19.02-56.48 ppm as shown in Fig.(9).

FT-IR spectrum of compound [3] $\left(\mathrm{H}_{2} \mathrm{C}-\mathrm{CH}\right)_{\mathrm{n}}$ showed characteristic absorption bands at 1596 $\mathrm{cm}^{-1}, 3070 \mathrm{~cm}^{-1}, 1049 \mathrm{~cm}^{-1}, 1542 \mathrm{~cm}^{-1}$ and $617 \mathrm{~cm}^{-1}$ due to $v(\mathrm{C}=\mathrm{C})$ aromatic, $v(\mathrm{C}-\mathrm{H})$ aromatic, $\quad v(\mathrm{C}-\mathrm{Cl}), \quad v(\mathrm{C}=\mathrm{N})$ thiazole ring and $v(\mathrm{C}-\mathrm{S})$ thiazole ring respectively.

UV spectrum showed an absorption $\lambda_{\max }$ at $299 \mathrm{~nm}$ which was attributed to $\left(\pi \rightarrow \pi^{*}\right)$.

${ }^{1} \mathrm{H}-\mathrm{NMR}$ spectrum of polymer [3] showed a signal at $\delta 7.867 \mathrm{ppm}(1 \mathrm{H}$, singlet) was attributed to (-NH) proton, and the signal between $\delta(7.223-7.767)$ ppm for three aromatic protons $\left(1 \mathrm{H}^{4}\right.$, $\left.1 \mathrm{H}^{5}, 1 \mathrm{H}^{6}\right)$, while the signal at $\delta 2.793$ ppm $(1 \mathrm{H}$, multiplet) was attributed to (-CH) for polymer group

and the signal at $\delta 1.501 \mathrm{ppm}(2 \mathrm{H})$ was attributed to the $\left(\mathrm{H}_{2} \mathrm{C}-\right)$ protons for polymer group ${ }\left(\mathrm{H}_{2} \mathrm{C}-\mathrm{CH}\right)_{n}$. The ${ }^{13} \mathrm{C}$ NMR spectrum of [3] showed signal at 168.24 ppm for carbonyl group $(\mathrm{C}=\mathrm{O})$, and the signals at 119.03-135.00 ppm due to aromatic carbons, while the signal at $151.41 \mathrm{ppm}$ was attributed to carbon atom in thiazole ring, and $\left(\mathrm{H}_{2} \mathrm{C}-\mathrm{CH}\right)_{\mathrm{n}}$ showed signals at (39.13-40.79) ppm .

UV spectrum showed an absorption $\lambda_{\max }$ at $300 \mathrm{~nm}$ which was attributed to $\left(\pi \rightarrow \pi^{*}\right)$.

FT-IR spectrum of compound [5], showed characteristic absorption bands at $1620 \mathrm{~cm}^{-1}, \quad 3139 \mathrm{~cm}^{-1}, 1550$ $\mathrm{cm}^{-1}$ and $617 \mathrm{~cm}^{-1}$ due to $v(\mathrm{C}=\mathrm{C})$ aromatic, $v(\mathrm{C}-\mathrm{H})$ aromatic, $v(\mathrm{C}=\mathrm{N})$ , thiazole ring, $v(\mathrm{C}=\mathrm{O})$ and $v(\mathrm{C}-\mathrm{S})$ thiazole ring respectively as shown in Table (4).Fig(2).

UV spectrum showed an absorption $\lambda_{\max }$ at $300 \mathrm{~nm}$ which was attributed to $\left(\pi \rightarrow \pi^{*}\right)$. ${ }^{1} \mathrm{H}-\mathrm{NMR}$ spectrum of [5] showed a signal at $\delta 8.243 \mathrm{ppm}$ was attributed to $(-\mathrm{NH})$ proton, while signal at $\delta 3.188 \mathrm{ppm}$ for $\left(3 \mathrm{H}\right.$, singlet) was attributed to $\left(\mathrm{CH}_{3}\right)$ proton, and the signal at $\delta 2.551 \mathrm{ppm}$ $(1 \mathrm{H})$ was attributed to $(-\mathrm{CH})$ for polymer group $\left(\mathrm{H}_{2} \mathrm{C}-\mathrm{CH}\right)_{\mathrm{n}}$, while the signal at $\delta 1.159 \mathrm{ppm}(2 \mathrm{H})$ was attributed to the $\left(\mathrm{CH}_{2}\right)$ protons for polymer group , and a signal between $\delta(7.955-8.204) \mathrm{ppm}$ for aromatic hydrogen $\left(3 \mathrm{H}\left(\mathrm{H}^{4}+\mathrm{H}^{5}+\mathrm{H}^{6}\right)\right)$ The ${ }^{13} \mathrm{C}$ NMR spectrum of [5] showed the signal at $171.56 \mathrm{ppm}$ for carbonyl group $\mathrm{N}(\mathrm{C}=\mathrm{O})$, and the signal at $132.65 \mathrm{ppm}$ belong to carbon atom in the thiazole ring, while the signal at $35.22 \mathrm{ppm}$ for carbon of methyl group $\left(\mathrm{CH}_{3}\right)$, and the signal at (103.30120.41) ppm attributed to aromatic carbon, and $\left.\mathrm{f}_{2} \mathrm{C}-\mathrm{CH}\right)_{\mathrm{n}}$ appeared at (40.12-55.36) ppm

FT-IR spectrum of compound [6] showed the same bands in compound [5], show in Table(4).

UV spectrum showed an absorption $\lambda_{\max }$ at $300 \mathrm{~nm}$ which was attributed to $\left(\pi \rightarrow \pi^{*}\right)$. As shown in Fig.(7).

FT-IR spectrum of compound [7] showed stretching bands at $1620 \mathrm{~cm}^{-1}$ aromatic $\mathrm{v}(\mathrm{C}=\mathrm{C}), 3078 \mathrm{~cm}^{-1}$ aromatic $v(\mathrm{C}-\mathrm{H}), 1542 \mathrm{~cm}^{-1}$ thiazole $v(\mathrm{C}=\mathrm{N})$, , $1635 \mathrm{~cm}^{-1}$ thiazole $v(\mathrm{C}=\mathrm{O}), 663 \mathrm{~cm}^{-1}$ thiazole $v(\mathrm{C}-\mathrm{S})$ and $1265 \mathrm{~cm}^{-1}$ methoxy group $v(\mathrm{C}-\mathrm{O}-\mathrm{C})$, shown in Table (4).

UV spectrum showed an absorption $\lambda_{\max }$ at $300 \mathrm{~nm}$ which was attributed to $\left(\pi \rightarrow \pi^{*}\right)$.

FT-IR spectrum of compound [8] showed characteristic absorption bands at $1643 \mathrm{~cm}^{-1}, 3178 \mathrm{~cm}^{-1}, 1334 \mathrm{~cm}^{-1}$, $1519 \mathrm{~cm}^{-1}$ and $663 \mathrm{~cm}^{-1}$ due to $v(\mathrm{C}=\mathrm{C})$ aromatic, $v(\mathrm{C}-\mathrm{H})$ aromatic, $v\left(\mathrm{C}-\mathrm{NO}_{2}\right)$, $v(\mathrm{C}=\mathrm{N})$ thiazole and $v(\mathrm{C}-\mathrm{S})$ thiazole respectively as shown in Table (4) .

UV spectrum showed an absorption $\lambda_{\max }$ at $272 \mathrm{~nm}$ and $385 \mathrm{~nm}$ which were attributed to $\left(\mathrm{n} \rightarrow \pi^{*}\right) \quad\left(\pi \rightarrow \pi^{*}\right)$. As shwon in Fig.(6). 
The ${ }^{1} \mathrm{H}$-NMR spectrum of [8] showed a signal between $\delta(7.402-8.109) \mathrm{ppm}$ for the three aromatic hydrogen $\left(1 \mathrm{H}^{4}\right.$, $1 \mathrm{H}^{5}, 1 \mathrm{H}^{6}$ ) while a signal at $8.262 \mathrm{ppm}$ $(1 \mathrm{H}$, signlet) was attributeed to $(-\mathrm{NH})$ proton, and the signal at $\delta 2.502 \mathrm{ppm}$ was attributed to $(-\mathrm{CH})$ for polymer group, $\left.{ }^{-} \mathrm{H}_{2} \mathrm{C}-\mathrm{CH}\right)_{n}$, while the signal at $\delta 1.056 \mathrm{ppm}(2 \mathrm{H})$ was attributed to $\left(\mathrm{H}_{2} \mathrm{C}\right.$-) protons for polymer group

${ }^{13} \mathrm{C}$-NMR spectrum of [8] showed the signal at $172.25 \mathrm{ppm}$ for carbonyl group $(\mathrm{C}=\mathrm{O})$, and the signal at 159.07 for carbon atom in thiazole ring, while the signal at 117.31-132.04 ppm for aromatic carbons, $\left(\mathrm{H}_{2} \mathrm{C}-\mathrm{CH}\right)_{\mathrm{n}}$ appeared signals at (119.62-56.48) ppm .FT-IR spectrum of compound [9] showed the same bands in compound [8] as shown in Table (4), Fig.(3).
UV spectrum showed an absorption $\lambda_{\max }$ at $268 \mathrm{~nm}$ and $359 \mathrm{~nm}$ which was attributed to $\left(\mathrm{n} \rightarrow \pi^{*}\right)$ and $\left(\pi \rightarrow \pi^{*}\right)$. The ${ }^{1} \mathrm{H}-\mathrm{NMR}$ spectrum of [9], showed a signal at $\delta 8.805 \mathrm{ppm}(1 \mathrm{H}$, singlet) was attributed to (-NH) proton, and the signal at $\delta 3.102 \mathrm{ppm}$ was attributed to (-CH) for polymer group $\mathrm{fH}_{2} \mathrm{C}-\mathrm{CH}{ }_{-}$ while the signal at $\delta 1.513 \mathrm{ppm}(2 \mathrm{H})$ was attributed to $\left(\mathrm{CH}_{2}\right)$ protons for polymer group $\left(\mathrm{H}_{2} \mathrm{C}-\mathrm{CH}\right)_{\mathrm{n}}$, and the signal between $\delta(7.100-8.156) \mathrm{ppm}$ for two aromatic protons $\left(1 \mathrm{H}^{4}, 1 \mathrm{H}^{5}\right)$.

${ }^{13} \mathrm{C}-\mathrm{NMR}$ spectrum of [9] showed signal at $176.17 \mathrm{ppm}$ for carbonyl group $(\mathrm{C}=\mathrm{O})$, and the signal at 150.28 ppm attributed to carbon atom in thiazole ring,while the signal at (120.24-135.58) ppm for aromatic carbons, and $\left.{ }^{-\mathrm{H}_{2} \mathrm{C}-\mathrm{CH}}\right)_{\mathrm{n}}$ appeared a signal at (39.14-40.80) ppm,

Table(2):physical properties of the prepared heterocyclic polyacrylamide

\begin{tabular}{|c|c|c|c|c|c|c|}
\hline $\begin{array}{c}\text { Code } \\
\#\end{array}$ & Structure & $\%$ Conversion & $\begin{array}{l}\text { Softening } \\
\text { point } \\
{ }^{\circ} \mathrm{C}\end{array}$ & $\begin{array}{c}\text { m.p. } \\
{ }^{\circ} \mathrm{C}\end{array}$ & Colour & $\begin{array}{l}\text { Solvent } \\
\text { used in } \\
\text { reaction }\end{array}$ \\
\hline 1 & $\begin{array}{c}\mathrm{S}_{1}^{\prime} \quad \stackrel{\mathrm{C}}{\mathrm{C}}=\mathrm{O} \\
\left(\mathrm{CH}_{2}-\mathrm{CH}_{\mathrm{n}}\right)_{\mathrm{n}} \\
\text { poly [-(N-acryl) amino-4-nitro- } \\
\text { 6-chlorobenzothiazole] }\end{array}$ & 76 & $185-215$ & $>360$ & $\begin{array}{c}\text { Yellowish } \\
\text { brown }\end{array}$ & $\begin{array}{l}\text { THF } \\
\text { DMF }\end{array}$ \\
\hline 2 & $\begin{array}{c}\mathrm{S}_{2} \quad \stackrel{\mathrm{I}}{\mathrm{I}}=\mathrm{O} \\
\text { poly [2-(N-acryl) amino-4-chloro- } \\
\text { 6-nitrobenzothiazole] }\end{array}$ & 87.5 & $200-225$ & $>360$ & $\begin{array}{l}\text { Yellowish } \\
\text { brown }\end{array}$ & $\begin{array}{l}\text { THF } \\
\text { DMF }\end{array}$ \\
\hline 3 & $\begin{array}{c}\left(\mathrm{CH}_{2}-{ }_{\mathrm{C}}^{\mathrm{C}}\right)_{\mathrm{n}} \\
\text { poly [2-(N-acryl) amino-6-chloro } \\
\text { benzothiazole }]\end{array}$ & 63.5 & $220-250$ & $\begin{array}{l}287- \\
295\end{array}$ & $\begin{array}{c}\text { Brownish } \\
\text { yellow }\end{array}$ & $\begin{array}{l}\text { THF } \\
\text { DMF }\end{array}$ \\
\hline 4 & 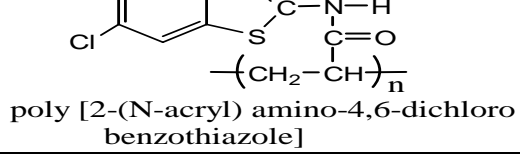 & 60 & $220-255$ & $>360$ & Gray & $\begin{array}{l}\text { THF } \\
\text { DMF }\end{array}$ \\
\hline 5 & 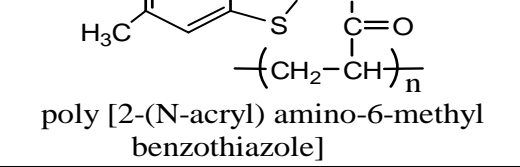 & 70 & $180-210$ & $>360$ & White & $\begin{array}{l}\text { THF } \\
\text { DMF }\end{array}$ \\
\hline
\end{tabular}




\begin{tabular}{|c|c|c|c|c|c|c|}
\hline 6 & $\begin{array}{c}\text { poly [2-(N-acryl) amino-4,6-dimethyl } \\
\text { benzothiazole] }\end{array}$ & 62 & $190-230$ & $\begin{array}{l}256- \\
262\end{array}$ & $\begin{array}{l}\text { Reddish } \\
\text { yellow }\end{array}$ & $\begin{array}{l}\text { THF } \\
\text { DMF }\end{array}$ \\
\hline 7 & $\begin{array}{c}\mathrm{H}_{3} \mathrm{I}_{\mathrm{I}}^{\mathrm{C}}=\mathrm{O} \\
\left(\mathrm{CH}_{2}-\mathrm{C}_{\mathrm{C}}\right)_{\mathrm{n}} \\
\text { poly [2-(N-acryl) amino-6-methoxy } \\
\text { benzothiazole] }\end{array}$ & 70 & $230-255$ & $>360$ & Black & $\begin{array}{l}\text { THF } \\
\text { DMF }\end{array}$ \\
\hline 8 & $\begin{array}{c}-\mathrm{S}^{\prime} \quad \stackrel{1}{\mathrm{C}}=\mathrm{O} \\
\left(\mathrm{CH}_{2}-\mathrm{CH}\right)_{\mathrm{n}} \\
\text { benzothiazole }]\end{array}$ & 61 & $180-205$ & $>360$ & $\begin{array}{l}\text { Very dark } \\
\text { gray }\end{array}$ & $\begin{array}{l}\text { THF } \\
\text { DMF }\end{array}$ \\
\hline 9 & $\begin{array}{c}\mathrm{S}^{\prime} \quad \stackrel{\mathrm{C}}{\mathrm{C}}=\mathrm{O} \\
\left(\mathrm{CH}_{2}-\mathrm{I}_{\mathrm{CH}}\right)_{\mathrm{n}} \\
\text { poly [2-(N-acryl) amino-4,6-dinitro } \\
\text { benzothiazole] }\end{array}$ & 66.6 & $172-190$ & $>360$ & Green & $\begin{array}{l}\text { THF } \\
\text { DMF }\end{array}$ \\
\hline
\end{tabular}

Table (3): Solubilities of the prepared heterocyclic poly acrylamides Abbreviation:- $\mathbf{S}=$ soluble, In = Insoluble, $\mathbf{P S}=$ Partial soluble, PSH = Partial soluble hot, PES = Petroleum ether spirit

\begin{tabular}{|c|c|c|c|c|c|c|c|c|c|c|c|c|}
\hline $\begin{array}{c}\text { Code } \\
\#\end{array}$ & Water & Ethanol & Dioxane & $\begin{array}{c}\text { Benzene } \\
\text { or } \\
\text { toluene }\end{array}$ & $\begin{array}{c}\text { CHCl } \\
\text { or } \\
\mathbf{C C l}_{\mathbf{4}}\end{array}$ & $\begin{array}{c}\text { Diethyl } \\
\text { ether }\end{array}$ & $\begin{array}{c}\text { Cyclo } \\
\text { hexane }\end{array}$ & Acetone & THF & DMF & DMSO & PES \\
\hline 1 & In & PS & In & In & In & In & In & PS & PS & PS & S & In \\
\hline 2 & In & PS & In & In & In & In & In & PS & PS & S & S & In \\
\hline 3 & In & In & In & In & In & In & In & In & PS & PS & S & In \\
\hline 4 & In & In & PS & In & In & In & In & PS & PS & PS & S & In \\
\hline 5 & In & In & In & In & In & In & In & In & In & PS & S & In \\
\hline 6 & In & In & In & In & In & In & In & In & In & PS & S & In \\
\hline 7 & In & In & In & In & In & In & In & In & PS & PS & S & In \\
\hline 8 & In & In & PS & In & In & In & In & PS & PS & PS & S & In \\
\hline 9 & In & In & PS & In & PS & In & In & PS & PS & PS & S & In \\
\hline
\end{tabular}




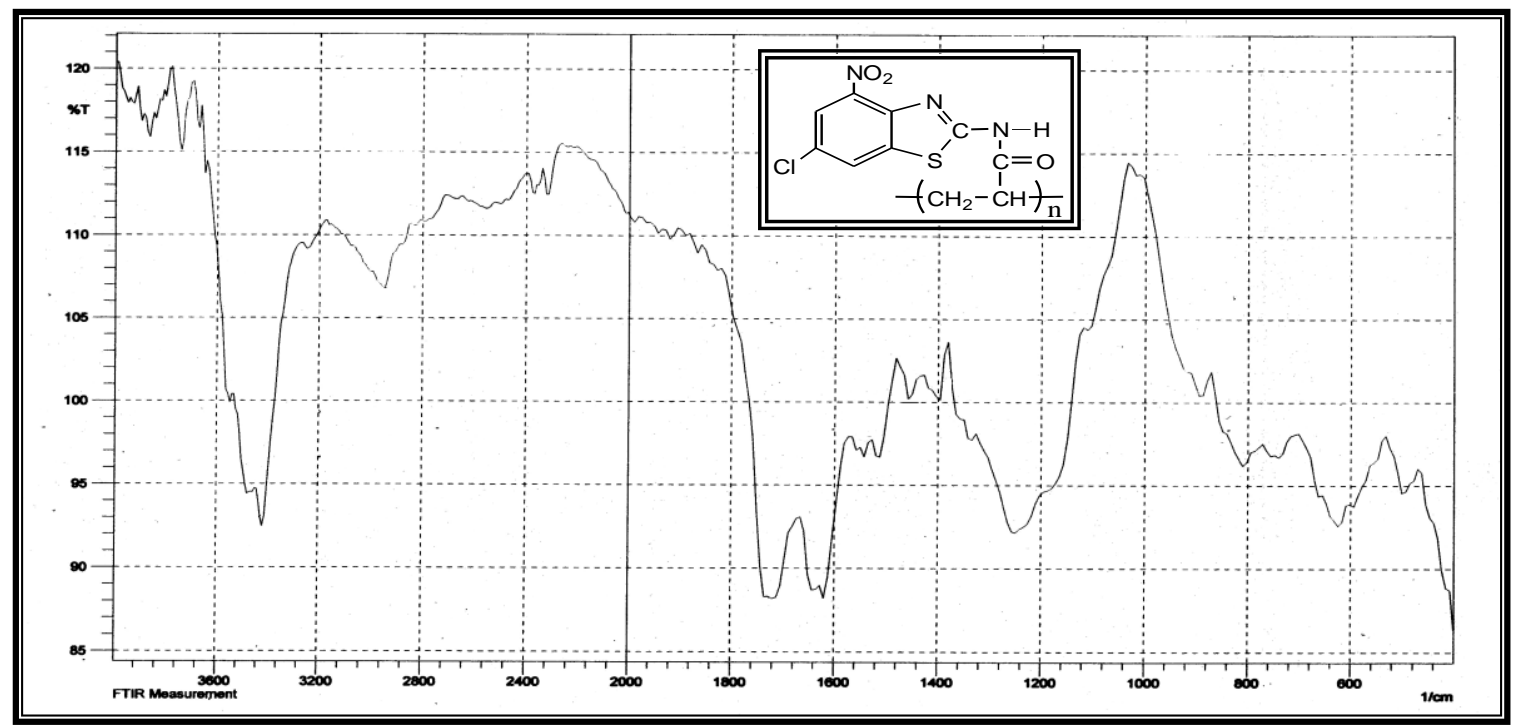

Fig. (1) : FT-IR spectrum of polymer [1]

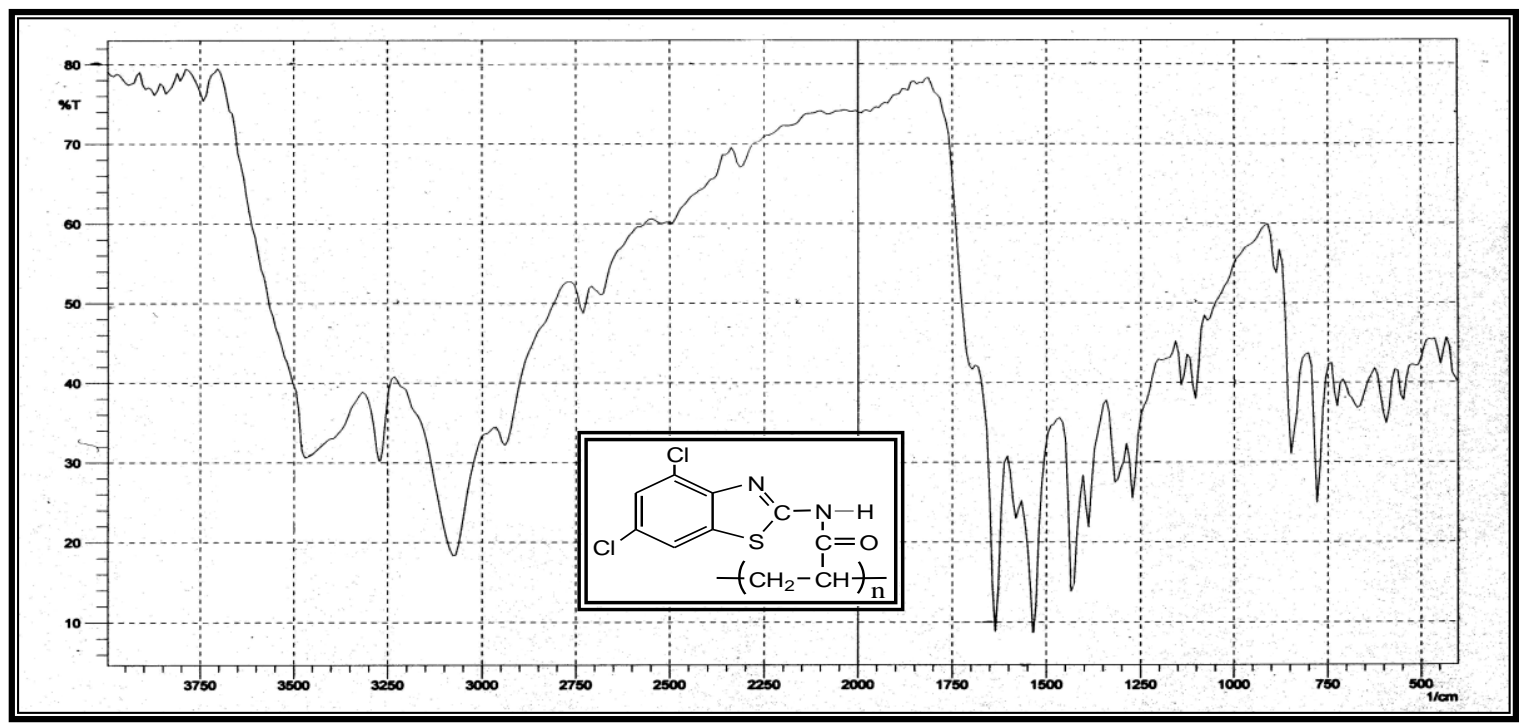

Fig. (2) : FT-IR spectrum of polymer [4]

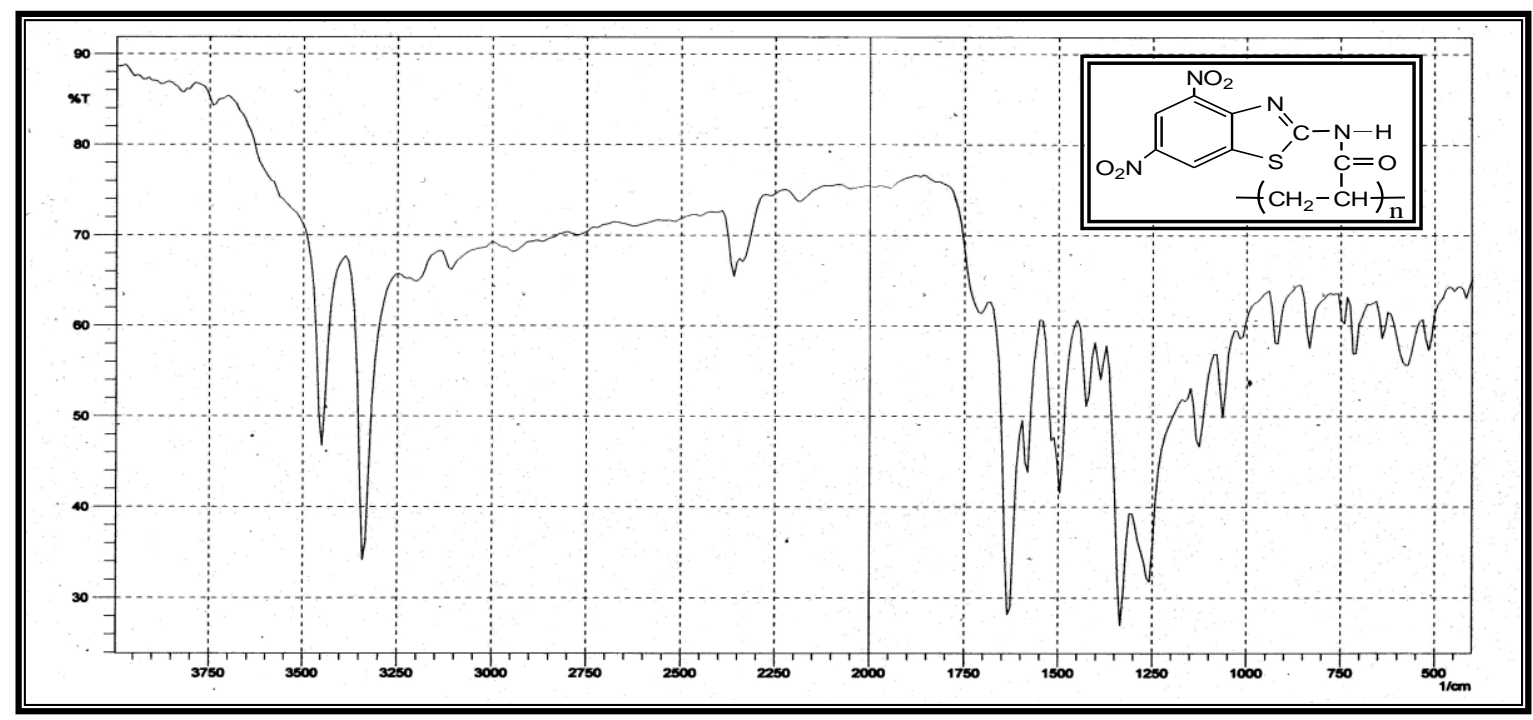

Fig.(3) : FT-IR spectrum of polymer [9] 


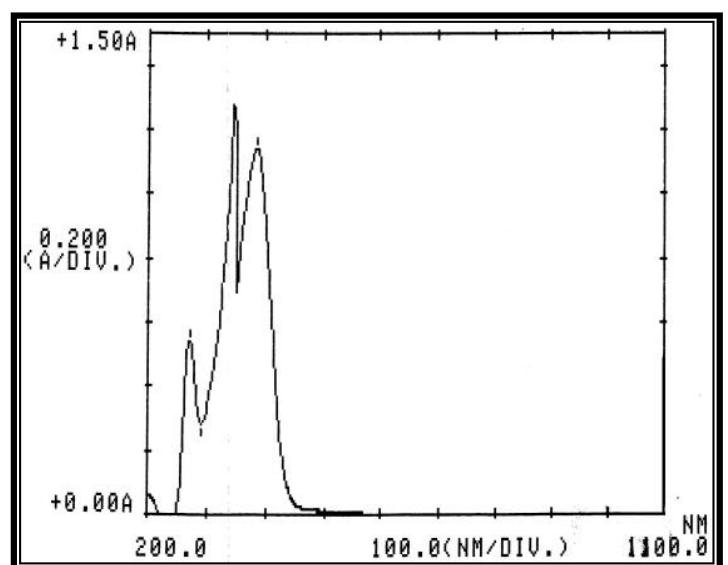

Fig. (4) : UV spectrum of polymer [2]

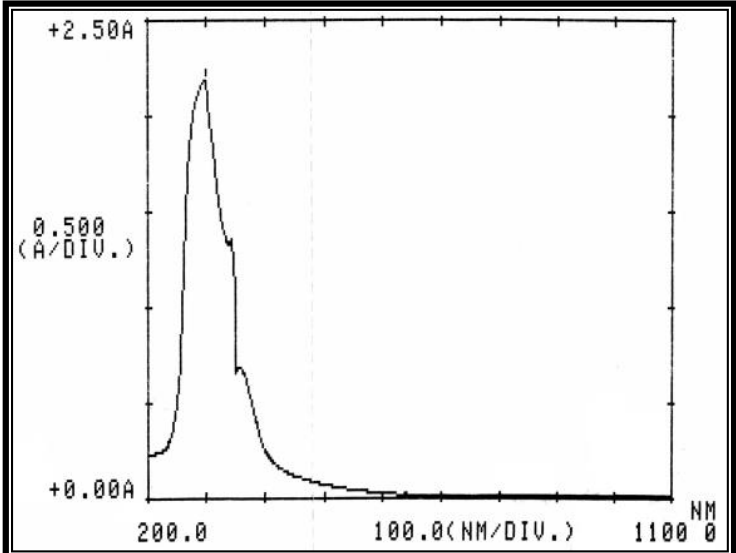

Fig. (5) : UV spectrum of polymer [1]
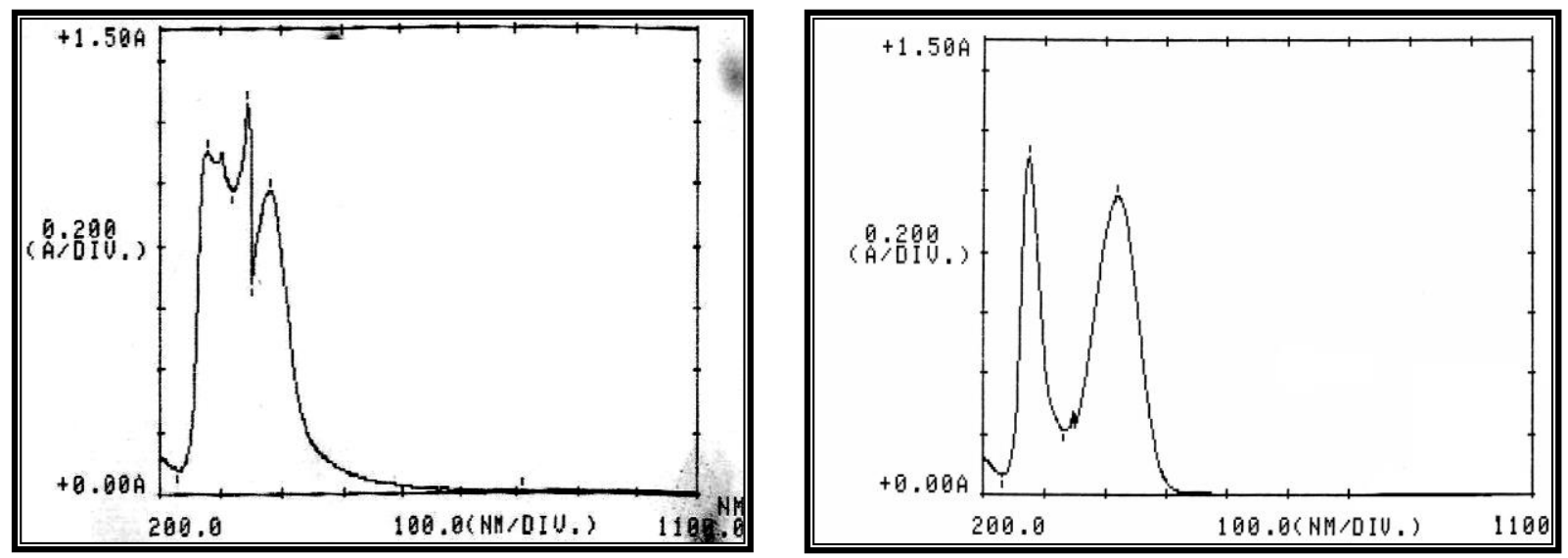

Fig. (6) : UV spectrum of polymer [8]

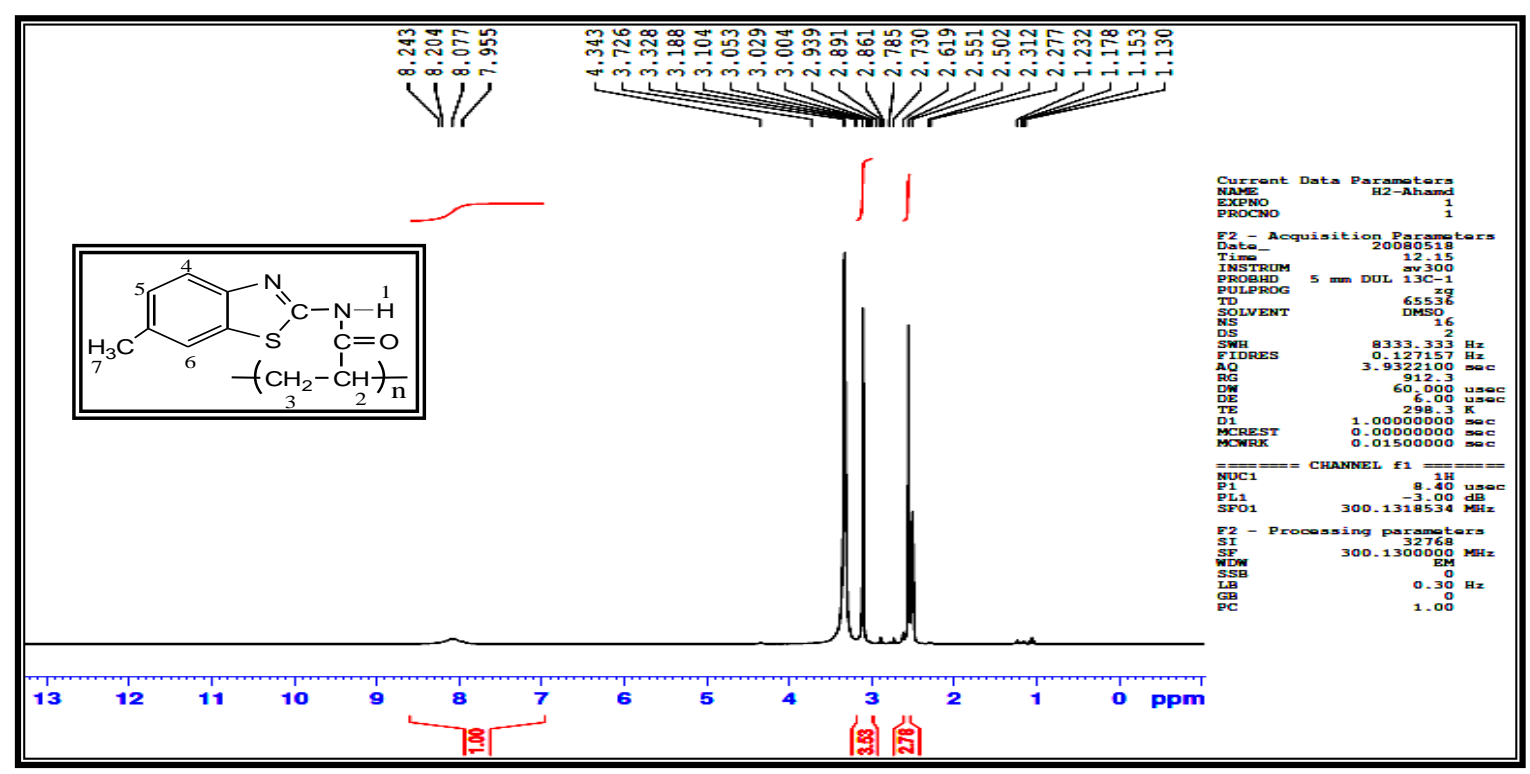

Fig. (10) : ${ }^{1}$ H-NMR spectrum of polymer [5] 


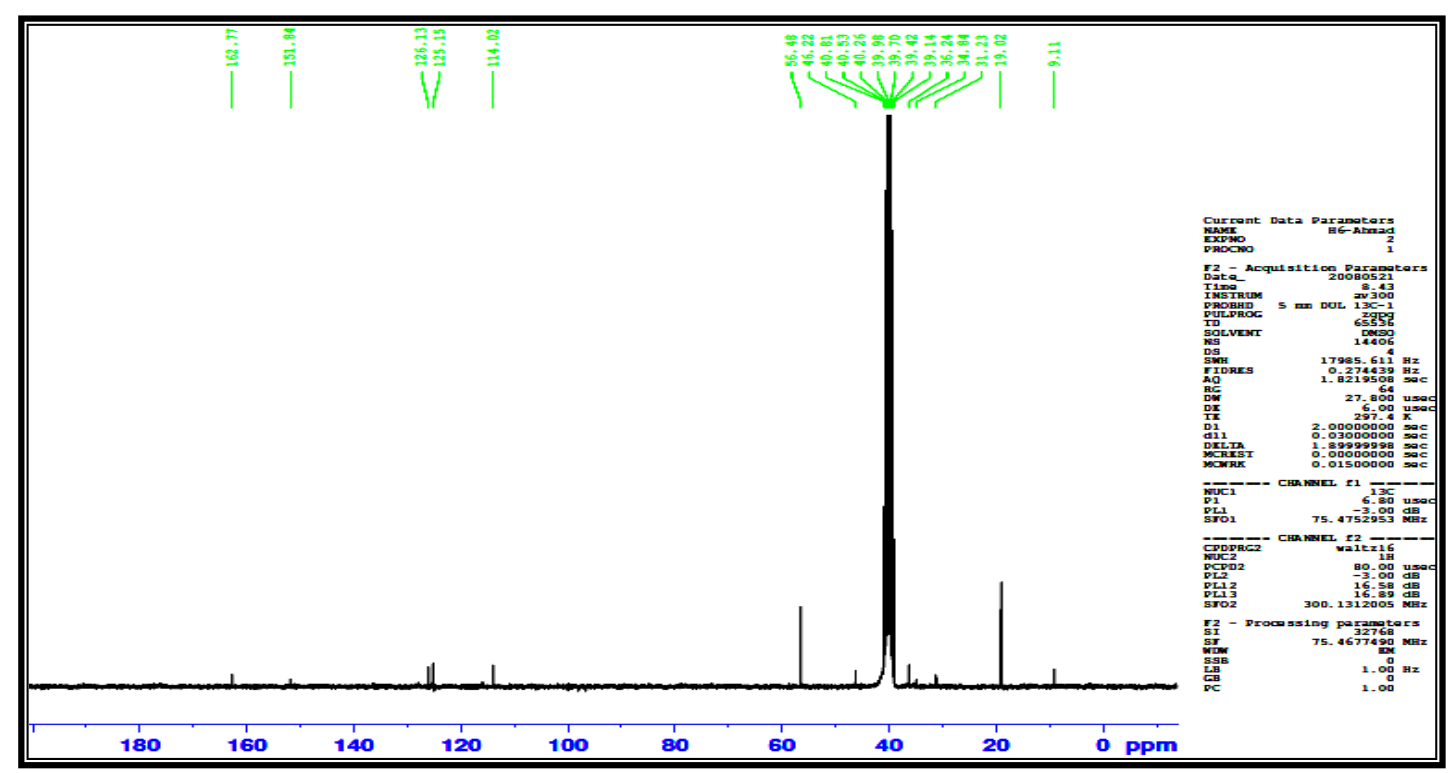

Fig.(9) : ${ }^{13}$ C-NMR spectrum of polymer [2]

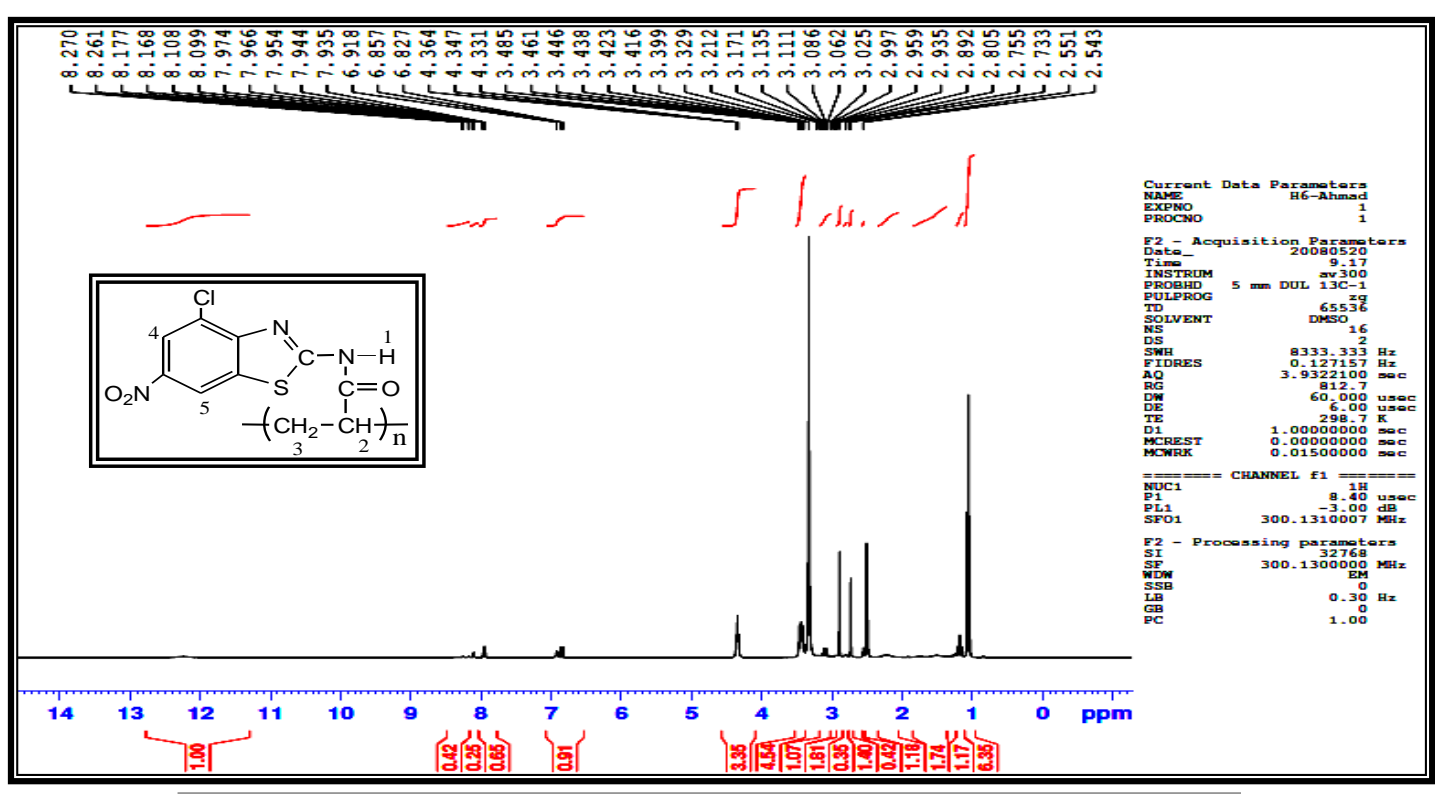

Fig. (8) : ${ }^{1} \mathrm{H}-\mathrm{NMR}$ spectrum of polymer [2] 
Table(4): FT-IR spectra of prepared Pheterocyclic polyacrylmides

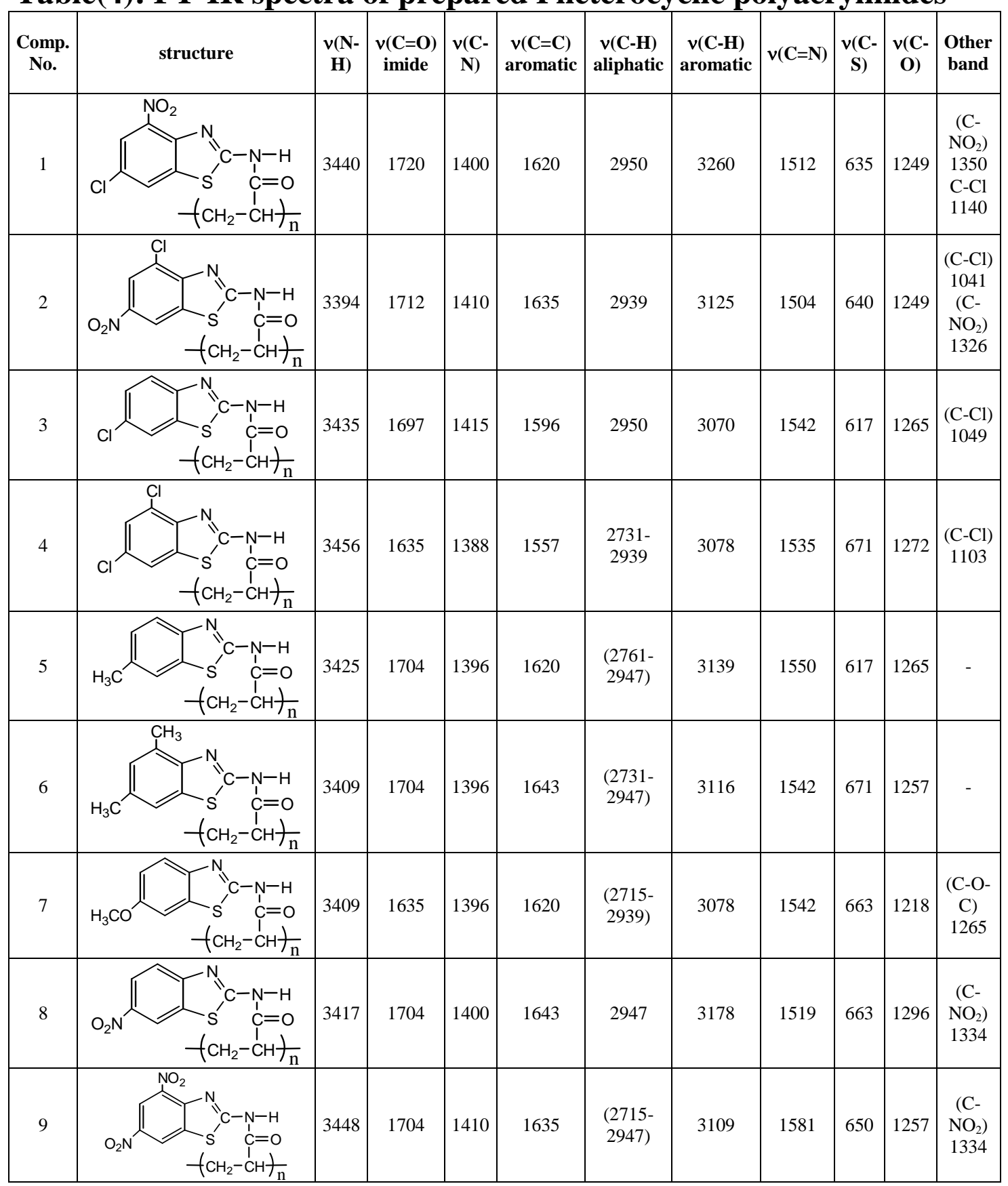

\section{References}

1- Ghalib, L. Raouf, R.M.and Adeel,H.J.2012 of the college of basic Education, .73:19-26.

2- Buneseu,A.Suncelme,M.and

Mailhot G.. 2008 Applied and Enviroonmental Microbiology , 74(10):2976-2984.

3- Tingshi,L. Shan Zhu, S. and BinYe,z. J. 2013.of Chemistry,(10) :1155-1170.
4- Shim,M.S.and Kwon Y.J. 2009. Bioconjugate Chem.,.20:488-499.

5- Wang,Z.Y. Chinese J.1999. of Polymer Science, 17(6):511-528.

6- Anderson,M.R. 2001. Ph.D. Thesis, Faculty of the Virginia Polytechnic Institute and State University.

7- Tengjao,H. L.and Fuming, J.2000. of Polymer Science, Part B, Polymer Physics,38:2077-2080. 
8- Colak;S.and Tew, G.N.2008. Macromolecules, 41:8436-8440,

9- Hacs,L.S. and Lee, J.KJ.2001. Appl. Polym. Sci., 82(10):2365-2371.

10- Stern,R. M. and Jedrzejas, J. 2006.

Chem. Rev., 106:818.

11- Mruthyunjayasawmy;B.H..2000.

Shanthareeappal, Indian J.Chem., 39:433,

12- Kuhait, A.G. M.Sc.1984. Thesis, Chemistry Department, College of Science, University of Baghdad.

13- Mahdi, S.A.R. 2008. M.Sc., Thesis, College of Science, University of Baghdad.

14- Carey,F.A. and Sundber R.J. 2007. "Advanced Organic Chemistry Part A:
Structure and Mechanisms", $5^{\text {th }}$ Ed., New York.

15- Tranter,J.C.and G.E. J.L2000. "Encyclopedia of Spectroscopy and spectrometry: part 1", Canada.

16- Silver stein,R.M.and Bassler. G.C.1967."Spectrometric identification of organic compounds", $2^{\text {nd }}$ Ed., John Wiley and Sons Ltd.

17- Solverst.R.M,Webster,F.X.,Kieml e.D.J. $2005 . \quad$ "Spectrometric identification of organic compounds", $7^{\text {th }}$ Ed., John Wiley and Sons, Inc.

18- Crews,P,Rodriguez,J, Jaspars. M. 1998. "Organic structure analysis", Oxford University Press, New York.

\section{تحضير وتثخيص بولي أكريل أميدات جديدة غير متجانسة من مشتقات2- أمينو بنزونايازول}

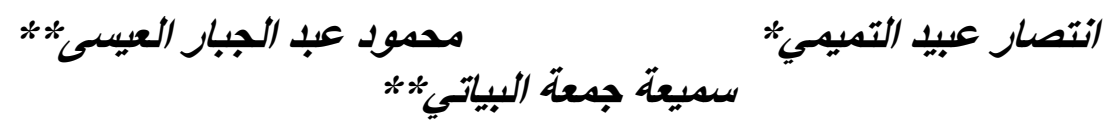

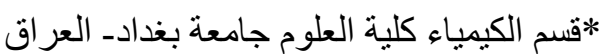

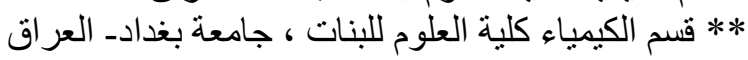

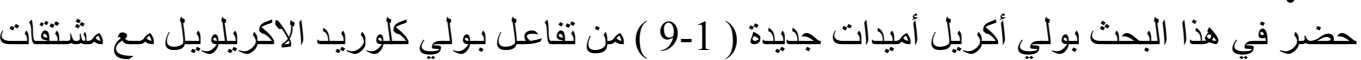

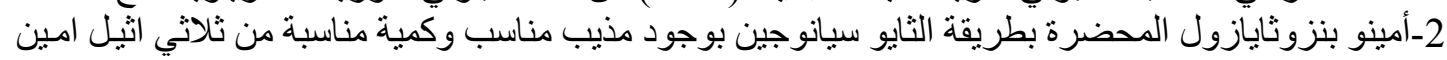

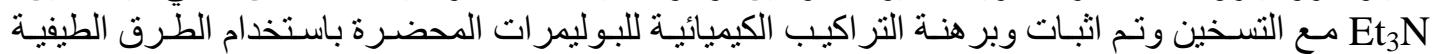

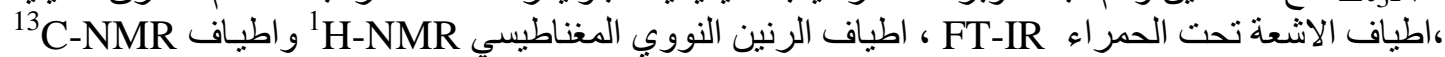

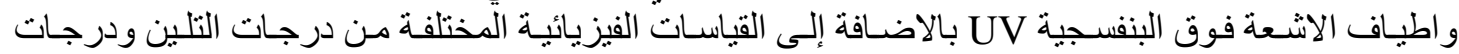
الانصهار و الذوبانية. 